\title{
MAJALAH IT-FLY VA: ALTERNATIF PILIHAN SUMBER BELAJAR BIOLOGI
}

\author{
Denti Meiningsih $^{1}$, Siti Alimah ${ }^{2}$, Yustinus Ulung Anggraito ${ }^{3}$ \\ ${ }^{1,2,3}$ Universitas Negeri Semarang-Kampus Sekaran, Kelurahan Sekaran, Kecamatan \\ Gunungpati 50229
}

\begin{abstract}
Abstrak
Penelitian ini bertujuan untuk menguji kelayakan majalah IT-FLY VA tentang keanekaragaman lalat buah di Agro Cepoko sebagai alternatif sumber belajar biologi. Metode penelitian yang digunakan adalah penelitian Research and Development (R\&D) modifikasi dari Borg and Gall dan Allesi \& Trollip melalui dua tahapan uji produk yaitu uji alfa dan uji beta. Uji alfa dalam penelitian ini dilakukan menggunakan lembar validasi penilaian kelayakan buku menurut BSNP 2014 yaitu teknik penyajian, isi, kebahasaan, dan kegrafikan yang diujikan kepada ahli materi dan media. Uji beta dilakukan untuk menguji produk dalam skala kecil. Uji beta dilakukan dengan menggunakan lembar validasi dan lembar tanggapan yang diujikan kepada pengguna yaitu guru dan siswa. Analisis hasil uji alfa yang dilakukan kepada ahli materi dan media menunjukkan kategori sangat layak pada aspek teknik penyajian, isi, dan kegrafikan. Pada aspek kebahasaan memperoleh kategori penilaian yang layak. Analisis hasil uji beta kepada guru dan siswa menunjukkan tanggapan yang positif terhadap majalah melalui lembar tanggapan siswa. Majalah It-Fly va yang ditulis berdasarkan hasil penelitian tentang lalat buah di Agro Cepoko memperoleh kriteria penilaian buku berdasarkan standar BSNP dengan kategori sangat layak digunakan sebagai alternatif pilihan sumber belajar biologi untuk siswa.
\end{abstract}

Kata kunci: Majalah IT-FLY, Sumber belajar, Lalat buah

\begin{abstract}
This study aimed to test the feasibility of the IT-FLY VA magazine about the diversity of fruit flies in Agro Cepoko as an alternative source of learning biology. The research method used the Research and Development (R\&D) modification of Borg and Gall and Allesi \& Trollip through two stages of product testing, namely the alpha test and beta test. Alpha test in this study was carried out using a book validation assessment sheet according to the 2014 BSNP namely presentation, content, linguistic, and graphic techniques that were tested to material and media experts. Beta testing was done to test the product on a small scale. Beta testing was done using validation sheets and response sheets that are tested to users, namely teachers and students. Analysis of the results of alpha tests conducted on material and media experts shows that the category is very feasible in the technical aspects of presentation, content, and graphics. In the linguistic aspect, they get a decent assessment category. Analysis of the results of the beta test to the teacher and students shows a positive response to the magazine through the student response
\end{abstract}

UNNES Semarang

Email: dentimeiningsih@gmail.com
(C2019 Universitas Islam Negeri Walisongo ISSN: 2088-7868, e-ISSN 2502-5708 
sheet. It-Fly va magazine which was written based on the results of research on fruit flies in Agro Cepoko obtained book evaluation criteria based on BSNP standards with a very suitable category to be used as an alternative choice for learning biology resources for students.

Keywords: IT-FLY magazine, Learning resources, Fruit flies

\section{PENDAHULUAN}

Biologi adalah salah satu cabang ilmu pengetahuan alam. Belajar biologi dengan memanfaatkan alam dan lingkungan sekitar sebagai sumber belajar dapat membuat pembelajaran menjadi lebih kontekstual. Mengenalkan makhluk hidup dan proses kehidupannya di lingkungan dengan mengkaitkan materi pada suatu contoh kontekstual pada lingkungan sekitar bertujuan agar siswa lebih memahami makna materi pelajaran yang dipelajarinya. Lingkungan di sekitar siswa dapat dimanfaatkan sebagai sumber belajar. Sumber belajar adalah segala sesuatu yang dapat digunakan siswa untuk mendukung pembelajaran, salah satunya yaitu lingkungan dan buku teks siswa. Berdasarkan hasil analisis buku paket SMA kelas X dan Buku Sekolah Elektronik (BSE), materi keanekaragaman hayati dan animalia subbab insekta belum mengaplikasikan contoh yang kontekstual. Pada buku-buku tersebut baru memberikan contoh yang sudah biasa dan tanpa contoh konkret seperti contoh keanekaragaman jenis adalah kelapa, aren, palm, lontar dan contoh keanekaragaman gen adalah mangga manalagi, mangga harum manis, mangga gadung. Pada buku tersebut belum mengaitkan materi dengan contoh sehari-hari pada lingkungan sekitar. Peningkatan pemahaman dan pengetahuan siswa membutuhkan suatu tambahan sumber belajar atau alternatif sumber belajar lain dalam keberlangsungan pembelajaran. Alternatif sumber belajar ini dapat membantu guru untuk lebih mudah mengaitkan materi pembelajaran dengan kondisi yang ada pada lingkungan sekitar serta dapat untuk menambah wawasan pengetahuan siswa. Buku teks siswa kadang kala menyajikan gambar yang menimbulkan suatu miskonsepsi pada pemahaman siswa. Ada beberapa faktor penyebab miskonsepsi siswa yaitu menurut Khairaty et al. (2018) bahwa faktor-faktor yang menyebabkan terjadinya miskonsepsi adalah kurangnya ketertarikan siswa pada mata pelajaran biologi karena menganggap biologi sebagai pelajaran yang sulit; tidak adanya konfirmasi siswa terhadap konsep yang dimilikinnya; proses pembelajaran yang berpusat pada guru; tidak adanya sumber belajar yang tetap sehingga guru menjadi satu-satunya sumber informasi siswa yang paling dominan. Hal ini senada dengan penelitian Farihah, et al. (2016) dan 
Septian (2018) bahwa faktor lain yang berpotensi menyebabkan miskonsepsi adalah gambar yang kurang representatif pada sumber belajar siswa.

Majalah It Fly va merupakan suatu majalah hasil penelitian biologi yang dapat memperkaya literasi siswa tentang pengetahuan mengenai keanekaragaman hayati, serangga, pengelolaan limbah pertanian, serta upaya dan teknologi dalam pengendalian hama dan membangkitkan motivasi siswa untuk belajar sehingga layak dijadikan alternatif sumber belajar. Sesuai dengan pendapat Santyasa (2007: 13) bahwa majalah merupakan media komunikasi masa dalam bentuk cetak yang berfungsi menyajikan bacaan yang aktual, memuat data terakhir tentang hal yang menarik perhatian, memperkaya pengetahuan, serta membangkitkan motivasi pembaca. Majalah yang dikembangkan berukuran kuarto (A4) dengan rincian 210 x $297 \mathrm{~mm}$. Beberapa hasil penelitian menyatakan bahwa majalah layak digunakan sebagai sumber belajar, di antaranya hasil penelitian Dani (2017) menunjukkan bahwa majalah Biomagz sebagai alternatif sumber belajar mandiri layak digunakan pada mata pelajaran biologi. Hasil penelitian Pratiwi et al. (2017) menunjukkan bahwa majalah biologi sebagai media pembelajaran layak digunakan pada pokok bahasan protista.

Majalah It-Fly va dapat digunakan peserta didik untuk mengamati keanekaragaman lalat buah melalui foto lalat buah. Majalah ini mendukung sumber belajar utama yang menarik, kontekstual, update, dan peduli terhadap lingkungan. Pengetahuan mengenai bioekologi lalat buah diharapkan dapat menambah pengetahuan masyarakat mengenai lalat buah hama dan penanganannya sehingga tetap dapat menjaga kelestarian lingkungan. Tujuan yang ingin dicapai dalam penelitian ini yaitu menguji kelayakan majalah It-Fly va yang sengaja ditulis berdasarkan hasil penelitian tentang keanekaragaman lalat buah di Agro Cepoko sebagai alternatif pilihan sumber belajar biologi yang memuat pengetahuan mengenai keanekaragaman hayati, serangga, pengelolaan limbah, serta upaya dan teknologi pengendalian lalat buah.

\section{METODE PENELITIAN}

Penelitian ini dilaksanakan di SMA Negeri 12 Semarang pada bulan Februari 2019. Metode penelitian ini adalah metode Research and Development (R\&D) modifikasi dari Borg and Gall (2003: 571) dan Allesi \& Trollip (2001: 548) melalui dua tahapan uji produk yaitu uji alfa dan uji beta. Uji alfa dalam penelitian ini dilakukan 
menggunakan lembar validasi penilaian kelayakan buku yang diadaptasi dari BSNP 2014 meliputi empat komponen kelayakan yaitu teknik penyajian, isi, kebahasaan, dan kegrafikan yang diujikan kepada ahli materi dan media.

Uji beta dalam penelitian ini dilakukan untuk menguji produk dalam skala kecil. Uji beta dilakukan dengan menggunakan lembar validasi dan lembar tanggapan meliputi empat komponen kelayakan yaitu teknik penyajian, isi, kebahasaan, dan kegrafikan yang diujikan kepada pengguna yaitu guru dan siswa. Uji beta diberikan kepada siswa kelas X MIPA 1 yang telah mendapatkan materi pada KD 3.2. Sepuluh siswa dipilih melalui purposive sampling untuk mewakili siswa berkemampuan tinggi, sedang, dan rendah. Siswa dibagikan majalah It-Fly va yang telah direvisi berdasarkan hasil validasi ahli materi dan media pada uji alfa. Validasi majalah oleh siswa dilakukan menggunakan lembar tanggapan siswa terhadap majalah dan dilakukan uji rumpang yang bertujuan untuk menilai keterbacaan majalah. Peserta didik diminta untuk membaca majalah It-Fly va terlebih dahulu, kemudian baru mengisi lembar tanggapan dan uji rumpang.

\section{HASIL DAN PEMBAHASAN}

Majalah It-Fly va merupakan suatu majalah yang dikembangkan berdasarkan hasil penelitian biologi. Fakta yang disajikan dalam majalah It-Fly va sesuai dengan kenyataan, penggunaan majalah membawa kebermanfaatan, serta meminimalkan pengeluaran biaya dan waktu untuk pembelajaran. Majalah ini berisi penjelasan yang dilengkapi dengan foto-foto hasil penelitian. Pengujian kelayakan produk pada majalah It-Fly va ini dilakukan menggunakan uji alfa dan uji beta. Uji alfa menilai majalah dari segi kelayakan materi dan media. Komponen yang dinilai adalah komponen teknik penyajian, isi, kebahasaan, dan kegrafikan. Uji beta dilakukan pada pengguna majalah yaitu guru dan siswa. Hasil validasi uji alfa dan beta oleh ahli dan guru dapat dilihat pada Tabel 3.

Tabel 3. Hasil Review Validator Materi dan Media serta Guru terhadap Majalah

\begin{tabular}{ccccccc}
\hline No & Validasi & \multicolumn{4}{c}{ Komponen Kelayakan } & Rata- \\
\cline { 3 - 6 } rata \\
\hline 1 & Ahli materi & $77,08 \%$ & $82,5 \%$ & $63,89 \%$ & - & $75 \%$ \\
2 & Ahli media & - & - & - & $95,31 \%$ & $95,31 \%$ \\
3 & Guru biologi & $91,67 \%$ & $93,75 \%$ & $80 \%$ & $100 \%$ & $91,67 \%$ \\
& Rata-rata & $84,37 \%$ & $88,12 \%$ & $71,94 \%$ & $97,65 \%$ & $87,32 \%$ \\
& Kriteria & Sangat & Sangat & Layak & Sangat & Sangat \\
& layak & layak & layak & layak \\
\hline
\end{tabular}


Komponen yang dinilai dari penilaian kelayakan materi diantaranya adalah teknik penyajian, isi materi, dan kebahasaan. Aspek yang dinilai pertama yaitu teknik penyajian antara lain sistematika penyajian, keruntutan penyajian, bagian pendahuluan, glosarium, dan daftar pustaka. Indikator teknik penyajian memperoleh nilai presentase sebesar 77,08\%. Hal ini menunjukan bahwa, penyajian materi majalah It-Fly va memenuhi aspek-aspek penilaian yang sesuai dengan buku teks menurut peraturan BSNP tahun 2014. Perolehan skor cukup menunjukan bahwa majalah yang dikembangkan menyajikan isi materi konsep dari yang mudah ke sukar, dari yang sederhana ke yang kompleks, dari yang dikenal sampai yang belum dikenal. Kelengkapan penyajian majalah mempunyai kelengkapan penyajian isi yang lengkap. Kelengkapan tersebut diantaranya adalah sekapur sirih, daftar isi, pengenalan keanekaragaman hayati, pengenalan lalat buah, glosarium dan daftar pustaka.

Penyajian materi majalah diawali dengan deskripsi kondisi kebun buah Cepoko dilengkapi dengan data penelitian. Kemudian disambung dengan pengenalan keanekaragaman hayati yang terdapat pada kebun buah Cepoko tersebut. Lalu ditampilkan data tabel dari hasil penelitian keanekaragaman lalat buah di kebun buah Cepoko. Pada pendahuluan terdapat materi mengenai morfologi lalat buah secara umum dan dilanjutkan dengan penjelasan morfologi lalat buah setiap spesies yang ditemukan. Hal ini menunjukkan bahwa penyajian isi materi dari yang dikenal sampai yang belum dikenal. Setelah pembaca mengenal berbagai macam lalat buah dilengkapi dengan bagian-bagian tubuh lalat buah, disajikan materi mengenai siklus hidup lalat buah dan penjelasan mengenai lama hidupnya. Hal ini menunjukkan bahwa sistematika isi majalah ini runtut.

Konservasi lingkungan juga ditambahkan dalam majalah terkait dengan pemanfaatan ranting, daun, rumput serta jambu biji kristal yang busuk. Dengan memberikan pengetahuan mengenai menjaga kebersihan lingkungan dan sekitarnya dapat membawa pembaca melaksanakan konservasi lingkungan yang dapat meminimalisir kehadiran lalat buah sebab lalat buah senang sekali dengan tempat yang lembab dan buah-buah yang busuk. Hal ini didukung oleh penelitian Pralisaputri et al (2016), bahwa pengembangan buku berbasis SETS sebagai media pembelajaran memiliki kelebihan yaitu siswa lebih tertarik dengan bahan ajar yang banyak menggunakan penjelasan berupa gambar serta warna-warna yang menarik, selain itu 
siswa juga menyukai pembelajaran yang sifatnya mengaitkan materi dengan kejadian alam di sekitar mereka serta media booklet berbasis SETS efektif meningkatkan hasil belajar siswa sama halnya dengan penelitian. Majalah ditutup dengan memberikan ringkasan informasi mengenai keseluruhan isi majalah.

Komponen kedua aspek yang dinilai dalam kelayakan isi antara lain akurasi materi, akurasi fakta dan metode, serta kesesuaian dengan perkembangan ilmu. Validator memberikan skor penilaian yang tinggi yaitu pada skala tiga dan empat serta memperoleh nilai persentase sebesar $82,5 \%$. Perolehan skor yang tinggi menunjukan bahwa majalah yang dikembangkan menyajikan isi materi yang aktual sesuai dengan perkembangan ilmu. Contoh yang disajikan berasal dari lingkungan terdekat peserta didik dan dapat membuka wawasan peserta didik untuk mengenal keanekaragaman lalat buah. Uraian materi yang disajikan dalam majalah mendorong peserta didik untuk menambah pengetahuan yang belum diketahui, menimbulkan rasa senang ketika membaca, meningkatkan minat dan motivasi membaca siswa serta mendorong untuk mempelajari majalah tersebut secara tuntas. Majalah It-Fly va yang dikembangkan memiliki tampilan menarik dengan penjelasan disertai dengan gambar yang dapat memfokuskan siswa untuk memahami isi majalah. Hal ini sesuai dengan pendapat Handayaningrum (2010), bahwa buku yang dilengkapi dengan gambar dapat meningkatkan minat baca dan penguasaan konsep biologi siswa. Minat membaca siswa yang meningkat dalam mempelajari suatu materi pembelajaran maka akan meningkatkan pula hasil belajar siswa. Hal ini senada dengan penelitian Azis (2016) bahwa minat, dan motivasi berhubungan positif terhadap hasil belajar biologi pada siswa sesuai dengan penelitian dimana minat dan motivasi siswa yang umumnya tinggi menyebabkan hasil belajar biologi juga dalam kategori tinggi. Seorang siswa dapat mencapai hasil belajar yang baik jika ditunjang oleh minat dan motivasi siswa yang baik pula.

Komponen ketiga adalah dalam validasi materi adalah kebahasaan. Menurut BSNP 2014, aspek yang dinilai dalam kebahasaan antara lain keterbacaan, kesesuaian dengan kaidah bahasa Indonesia, kebakuan istilah, dan penggunaan istilah, simbol/ lambang serta nama ilmiah. Nilai persentase pada komponen kebahasaan yang diberikan oleh validator terhadap majalah yang dikembangkan yaitu $63,89 \%$. Hal ini menunjukan bahwa kriteria kebahasaan dalam majalah adalah layak. Perolehan persentase 
menunjukan bahwa materi dalam majalah yang dikembangkan menggunakan bahasa yang menarik, mudah dipahami, dan tidak menimbulkan multitafsir.

Validasi selanjutnya adalah validator tampilan kegrafikan dari majalah yang telah dikembangkan. Tampilan kegrafikan majalah divalidasi oleh ahli media. Komponen yang dinilai pada validasi tampilan kegrafikan adalah ukuran majalah, tata letak kover, tipografi kover majalah, tata letak isi majalah, tipografi isi majalah, dan penyajian foto. Komponen penilaian merujuk pada penilaian dari BSNP tahun 2014.

Hasil validasi tampilan kegrafikan majalah "It-Fly $v a$ " memperoleh nilai persentase sebesar 95,31\%. Ukuran majalah sudah memenuhi kriteria standar ukuran majalah menurut ISO A4, yaitu 210 mm x 297 mm. Unsur tata letak antara kover muka dan belakang merupakan suatu kesatuan yang utuh. Elemen ilustrasi, warna, dan tipografi ditampilkan secara padu dan saling terikat satu sama lain. Warna yang digunakan adalah dominasi hijau kecoklatan dan hijau sesuai dengan materi isi majalah. Warna hijau kecoklatan merupakan warna dominan sesuai tema yaitu lalat buah sedangkan warna hijau berkaitan erat dengan alam, lingkungan, serta ramah lingkungan (Rahayu, 2012). Pada aspek tipografi kover, majalah yang dikembangkan menggunakan ukuran huruf judul lebih dominan, warna judul lebih kontras dibandingkan warna dasar kover. Huruf yang digunakan sesuai dengan materi dan bukan merupakan huruf hias/ dekorasi. Ilustrasi pada kover majalah sudah mengungkapkan karakter objek yang akan dipelajari.

Semua aspek pada tampilan kegrafikan hampir memperoleh nilai sempurna, kecuali pada 3 aspek yaitu warna unsur tata letak; bentuk, warna, ukuran objek sesuai realita; dan penempatan ilustrasi dan keterangan gambar. Majalah yang dikembangkan mendapat masukan supaya memadukan warna yang hampir senada supaya warna tidak berpendar sehingga membuat mata silau. Oleh karena itu, selanjutnya majalah diperbaiki dengan memadukan beberapa warna yang tingkat gradasinya berdekatan supaya tidak membuat mata silau dan lelah. Dengan demikian, majalah telah mencapai standar kelayakan bahan ajar menurut BSNP tahun 2014 yang meliputi empat komponen, yaitu komponen kelayakan isi, kebahasaan, penyajian, dan kegrafikan.

Uji beta terhadap produk dilakukan oleh guru dan siswa. Pada uji beta ini dilakukan uji coba skala kecil pada sepuluh peserta didik kelas X MIPA 1 SMA Negeri 12 Semarang dengan tingkat kemampuan yang berbeda. Penentuan responden dapat 
dilihat dari nilai Ulangan Harian pada kelas tersebut. Peserta didik diminta mengisi uji rumpang, yaitu teknik tes tertulis untuk menguji peserta didik dengan cara mengisi kekosongan kata dari beberapa paragraf dalam sebuah bacaan. Uji rumpang berfungsi sebagai alat ukur keterbacaan suatu majalah yang telah dikembangkan. Uji rumpang tersebut diperoleh rata-rata persentase 82,67 \%. Kriteria keterbacaan majalah "It-Fly $v a$ " tergolong tinggi dan dapat digunakan oleh peserta didik dengan tingkat kemampuan tinggi hingga rendah. Hal ini dibuktikan dengan perolehan persentase peserta didik dengan tingkat kemampuan rendah lebih dari $60 \%$.

Peserta didik dengan tingkat kemampuan kategori rendah memperoleh presentase dalam katergori rendah dalam uji keterbacaan majalah. Hal ini dapat dikarenakan penggunaan bahasa dalam majalah yang kurang begitu mudah dimengerti oleh siswa dengan tingkat kemampuan rendah sehingga dalam uji keterbacaan majalah diperoleh skor dengan kategori rendah. Peserta didik juga diminta untuk mengisi angket tanggapan mengenai majalah yang dikembangkan. Pengisian angket bertujuan untuk mengetahui kelayakan majalah yang dikembangkan. Nilai rata-rata persentase yang diperoleh dari angket tanggapan peserta didik skala kecil sebesar 83,46\% dengan kriteria sangat layak. Kriteria sangat layak oleh peserta didik menunjukan bahwa majalah yang dikembangkan layak digunakan sebagai suplemen sumber belajar.

Majalah It-Fly va ini merupakan majalah hasil penelitian yang di dalamnya memuat fakta-fakta yang ada di lingkungan sekitar siswa. Fakta ilmiah pada lingkungan sekitar siswa akan memudahkan siswa untuk memahami konsep-konsep pembelajaran biologi. Hal ini senada dengan penelitian Arsana, et al. (2013) bahwa pendekatan pembelajaran kontekstual berbantuan media lingkungan sekitar dapat meningkatkan aktivitas dan hasil belajar ipa. Banyak juga siswa yang masih menganggap bahwa pembelajaran biologi itu sulit karena banyak materi yang harus dihafal dan terlalu banyak istilah ilmiah. Siswa mengganggap sulit karena mereka hanya menghafal konsep bukan memahami serta mengembangkan konsep. Memahami dan mengembangkan konsep akan lebih mudah jika kita kaitkan dengan fakta-fakta yang ada pada lingkungan sekitar siswa supaya pembelajaran menjadi lebih kontekstual. Pembelajaran yang kontekstual dapat meningkatkan aktivitas dan hasil belajar siswa. Hal ini sebanding dengan Rambulangi (2017) bahwa pembelajaran kontekstual merupakan konsep yang membantu guru mengaitkan antara materi yang diajarkan dengan situasi dunia nyata dan 
mendorong siswa membuat hubungan antara pengetahuan yang dimilikinya dengan penerapannya dalam kehidupan mereka sebagai anggota keluarga dan masyarakat sehingga pembelajaran kontekstual dapat meningkatkan aktivitas dan hasil belajar siswa.

Majalah It-Fly va mempunyai kelebihan sebagai produk hasil penelitian biologi tentang lalat buah pada tanaman jambu biji kristal di Agro Cepoko, Kota Semarang serta gambar jenis-jenis lalat buah yang ditemukan adalah hasil identifikasi. Majalah ItFly va di dalamnya terdapat berbagai materi di antaranya yaitu mengenal keanekaragaman hayati, kingdom animalia, phylum arthropoda, kelas insect, kunci identifikasi serangga menggunakan data morfologi, morfologi umum serangga, morfologi Bactrocera dan Drosophila, siklus hidup Bactrocera dan Drosophila, upaya dan kendala pengendalian, teknologi pengendalian lalat buah, serta pengelolaan limbah. Majalah ini dapat dimanfaatkan sebagai sumber belajar formal maupun non-formal. Sumber belajar formal yaitu pada lingkungan sekolah, majalah ini digunakan sebagai alternatif suplemen tambahan materi pada KD 3.2 yaitu menganalisis berbagai tingkat keanekaragaman hayati di Indonesia beserta ancaman dan pelestariannya beserta ancaman dan pelestariannya. KD 4.2 menyajikan hasil observasi berbagai tingkat keanekaragaman hayati di Indonesia dan usulan upaya pelestariannya keanekaragaman hayati. Pada KD 3.2 dapat memanfaatkan majalah It-Fly va pada topik mengenal keanekaragaman hayati, upaya dan kendala pengendalian serta pengelolaan limbah.

Pemanfaatan majalah It-Fly va dapat juga diterapkan pada KD 3.9 yaitu mengelompokkan hewan ke dalam filum berdasarkan lapisan tubuh, rongga tubuh simetri tubuh, dan reproduksi. KD 4. 9 Menyajikan laporan perbandingan kompleksitas lapisan penyusun tubuh hewan (diploblastik dan triploblastik), simetri tubuh, rongga tubuh, dan reproduksinya. Namun, KD 3.9 ini majalah hanya dapat diterapkan pada filum arthropoda dan kelas insecta saja. Pemanfaatan pada subbab ini terdapat pada topik kingdom animalia, phylum arthropoda, kelas insecta, kunci identifikasi berdasarkan data morfologi, morfologi umum serangga, morfologi Bactrocera dan Drosophila, siklus hidup Bactrocera dan Drosophila serta teknologi pengendalian lalat buah.

Menurut pakar materi dan media, majalah "It-Fly va" yang dikembangkan masih terdapat beberapa kekurangan di antaranya yaitu pada majalah hanya mencakup 
beberapa materi belum bisa mencakup semua bab yaitu keanekaragaman hayati tingkat genus dan spesies serta animalia pada sub bab arthropoda. Masih terlalu banyak tulisan daripada gambar dalam majalah. Pada pengembangan majalah "It-Fly va" ini baru dilakukan penelitian sampai kelayakan majalah saja, belum sampai keefektifannya dalam pembelajaran di dalam kelas. Adapun masukan untuk majalah yang dikembangkan ini yaitu nantinya konten dalam majalah dapat ditambahkan lagi sehingga mencakup pembelajaran dalam satu bab serta untuk penelitian lebih lanjutnya dapat diteliti efektifitas majalah tersebut dalam pembelajaran di kelas khususnya pada bab keanekaragaman hayati dan kingdom animalia.

\section{SIMPULAN}

Dengan demikian dapat disimpulkan bahwa berdasarkan hasil validasi uji alfa dan beta oleh ahli dan guru majalah "It-Fly va" yang ditulis berdasarkan hasil penelitian tentang keanekaragaman lalat buah di Agro Cepoko memperoleh skor rata-rata $87.3 \%$ sehingga masuk dalam kriteria penilaian sangat layak digunakan sebagai alternatif pilihan sumber belajar untuk siswa.

\section{DAFTAR PUSTAKA}

Alessi, S.M., \& Trollip, S.R. (2001). Multimedia for learning: methods and development (3rd Edition). Boston: Allyn and Bacon.

Arsana, Made, A. A. I. N. Marhaeni, \& I. Wayan Suastra. (2013). Implementasi Pendekatan Pembelajaran Kontekstual Berbantuan Media Lingkungan Sekitar untuk Meningkatkan Aktivitas dan Hasil Belajar IPA. E-journal program pascasarjana Universitas Pendidikan Ganesha, 3, 1-10.

Azis, Putri A. (2016). Hubungan Minat, Motivasi Belajar dan Sikap dengan Hasil Belajar Siswa Kelas VIII SMP Negeri 13 Makassar. Journal of EST, 2(3), 144151.

Dani, Husnul B. (2017). Pengembangan Majalah Biologi (Biomagz) pada Materi Virus sebagai Alternatif Sumber Belajar Mandiri Siswa Kelas X di MAN 1 Mataram. Jurnal Pendidikan Biologi FITK UIN Mataram, 10(1), 91-102.

Farihah, A. N., Krispinus, K. P., \& Aditya M. (2016). Analisis Miskonsepsi Materi Sistem Regulasi pada Siswa Kelas XI SMA Kota Semarang. Journal of Biology Education, 5(3), 319-329.

Gall, M. D., Gall, J. P., \& Borg, W. R. (2003). Education research: An introduction (7 
th Eds). Boston: Pearson Education, Inc.

Handayaningrum, Yulita. (2010). Penerapan Media Cerita Bergambar (Cergam) untuk Meningkatkan Minat Baca Biologi Siswa Pada Pokok Bahasan Bahan Kimia dalam Makanan Kelas VIII SMP Negeri 7 Surakarta Tahun Pelajaran 2008/2009. Skripsi tidak dipublikasikan. Universitas Sebelas Maret.

Khairaty, Nurul I., A. Mushawwir T., \& Hartati. (2018). Identifikasi Miskonsepsi Siswa pada Materi Sistem Peredaran Darah dengan Menggunakan Three-Tier di Kelas XI IPA 1 SMA Negeri 1 Bontonompo. Jurnal Nalar Pendidikan, 6(1), 7-13.

Pralisaputri, K.R., Heribertus, S., \& Chatarina, M. (2016). Pengembangan Media Booklet Berbasis Sets pada Materi Pokok Mitigasi dan Adaptasi Bencana Alam untuk Kelas X SMA. Jurnal GeoEco, 2(2), 147-154.

Pratiwi, Nurjannah, Gardjito, \& A. Hamidah. (2017). Pengembangan Majalah Biologi sebagai Media Pembelajaran pada Pokok Bahasan Protista Kelas X MIA di SMA N 7 Kota Jambi. Jurnal Biodik, 1(3), 27-34.

Rahayu, Adhifah. (2012). Peran Warna dalam Arsitektur sebagai Salah Satu Kebutuhan Manusia. Skripsi tidak dpublikasikan. Universitas Indonesia.

Rambulangi, Elisaberth. (2017). Peningkatan Hasil Belajar Pokok Bahasan Pertumbuhan Tanaman dengan Metode Pembelajaran Kontekstual Siswa Kelas X SMK Balla Kabupaten Mamasa. Jurnal Media Komunikasi Pendidikan Teknologi Kejuruan, 4(2), 83-91.

Santyasa, I Wayan. (2007). Landasan Konseptual Media Pembelajaran. Makalah Workshop Media Pembelajaran bagi guru-guru SMA N Banjar Angkan, 10 Januari 2007. Banjar Angkan Klungkung: Universitas Pendidikan Ganesha.

Septian, Irwin. (2018). Analisis Konsepsi Siswa pada Materi Keanekaragaman Hayati di SMA. Jurnal Untan, 1-12. 